\title{
Farmers' Participatory Evaluation of Alternate Wetting and Drying Irrigation Method on the Greenhouse Gas Emission, Water Productivity and Paddy Yield in Bangladesh
}

Mohammad Mobarak Hossain ${ }^{\text {a, * }}$, Mohammad Rafiqul Islam ${ }^{1}$

${ }^{a}$ Rice Breeding Innovation Platform, International Rice Research Institute, Bangladesh Country Office, Banani, Dhaka-1213, Bangladesh. Email: mm.hossain@irri.org (MMH); mr.islam@irri.org (MRI)

*Corresponding author: mm.hossain@irri.org

\section{ABSTRACT}

In dry season paddy farming, the alternate wetting and drying (AWD) irrigation improves water productivity, paddy production, and has the potential to decrease greenhouse gas $(\mathrm{GHG})$ such as methane $\left(\mathrm{CH}_{4}\right)$ and nitrous oxide $\left(\mathrm{N}_{2} \mathrm{O}\right)$ emissions when compared to continuous flooding $(\mathrm{CF})$. However, there is a lack of research in Bangladesh on the effects of water management on $\mathrm{CH}_{4}$ and $\mathrm{N}_{2} \mathrm{O}$ emissions. During November 2017-April 2018, participatory on-farm trials were conducted at Feni and Chattogram districts of Bangladesh. Total 105 farmers comprising 20-hectare of land (62 farmers at Feni and 43 farmers at Chattogram district, each location having 10 hectare of land). We compared irrigation water and cost reductions, paddy yield, and $\mathrm{CH}_{4}$ and $\mathrm{N}_{2} \mathrm{O}$ emissions from paddy fields irrigated using AWD and $\mathrm{CF}$ irrigation methods. The $\mathrm{CH}_{4}$ and $\mathrm{N}_{2} \mathrm{O}$ emissions were determined using the Cool Farm Beta-3 methodology, and the global warming potential (GWP) was estimated using the Intergovernmental Panel on Climate Change-2014 standard approach. The mean results of randomly selected 30 farmers from two locations (15 of each) showed that AWD remarkably decreased irrigation water consumption by about $24 \%$ and increased water productivity by $224 \%$. We estimated $23 \%$ savings for irrigation costs in AWD. By this time, AWD improved paddy production by $3 \%$ over CF. The AWD irrigation resulted in a $47 \%$ reduction in cumulative $\mathrm{CH}_{4}$ emissions having a lower $\mathrm{CH}_{4}$ emission factor $\left(0.74 \mathrm{~kg} \mathrm{ha}^{-1}\right.$ day-1) than $\mathrm{CF}\left(1.39 \mathrm{~kg} \mathrm{ha}^{-1} \mathrm{day}^{-}\right.$ ${ }^{1}$ ). There was no obvious difference in $\mathrm{N}_{2} \mathrm{O}$ emission between AWD and CF. When compared to CF, AWD decreased the overall GWP by $27 \%$ and lowered the GHG intensity by $42 \%$. The $\mathrm{CH}_{4}$ and $\mathrm{N}_{2} \mathrm{O}$ emissions did not differ substantially between Feni and Chattogram.

Keywords: Methane, nitrous oxide, global warming potential, water productivity, paddy yield.

\section{Introduction}

Rice (Oryza sativa L.) is the fundamental food to Bangladesh's survival. It is the primary source of nourishment for 164.6 million compatriots (BBS, 2020). The early monsoon Aus (upland rice), the monsoon Aman (wet season rice), and the dry winter Boro (dry season rice), are the three seasons in which rice is farmed. Among them, Boro rice is typically planted in November-December and harvested in late April-early May in properly irrigated conditions. Boro rice has expanded to $45.91 \%$ of total rice area in 2020 from $9 \%$ in $1966-67$ as a result to the advent of shallow water pumps (BBS, 2020). This growth necessitated extensive irrigation water consumption, leading groundwater tables to fall at a pace of $4 \mathrm{~cm}$ per year, resulting in a rising water shortage. Bangladeshi farmers are now spending roughly $30 \%$ of the entire cost of rice production for irrigation (Neogi et al., 2018) which is mainly operated by irrigation pump owners. 
Typically, pump owners offer irrigation water on a contractual basis for the duration of each season, so ensuring the continuity of farmers. He determines the complete irrigation program independently and at a set cost. The owner begins irrigating farmers' fields in his command area on one side and proceeds serially from one plot to the next until he reaches the last plot. Generally, farmers want to save as much water as possible throughout their irrigation shift. Additionally, most farmers feel that maintaining standing water in rice fields at all stages/phases is necessary to guarantee a larger harvest. They are spending around 2500-5000 liters of water to produce one kilogram of rice (Bouman et al., 2002; Bouman, 2009). But scientifically, this quantity of water does not require from a physiological standpoint as continuous standing water is needed only at transplanting, blooming and grain filling stage/phase to avoid water stress (Kürschner et al., 2010).

This usual approach of continuous flooding (CF) leads to substantial surface runoff, flow and infiltration, accounting for around $80 \%$ of total water consumption (USDA, 2019). By 2025, Asia's available water supplies per capita are anticipated to decrease by 15-54\% from 1990 levels (Subedia and Poudel, 2021). Like other ricegrowing regions on the Asian continent, Bangladesh is already experiencing water constraint, which means farmers need water-saving technology to produce rice with less water (Bouman et al., 2002). Due to Bangladesh's frequent water shortages, particularly during the dry Boro season, sufficient water to irrigate rice fields is increasingly scarce. Additionally, due to global warming, severe changes in the pattern of precipitation and drought have become more prevalent in recent decades, posing a substantial danger to manage water for rice farming soon (IPCC, 2019). The increased quantity of atmospheric greenhouse gases (GHGs) viz., $\mathrm{CH}_{4}$ and $\mathrm{N}_{2} \mathrm{O}$ is a significant contributor to global warming and climate change. Rice farming is accounting for about $11 \%$ and $6 \%$ of global $\mathrm{CH}_{4}$ and $\mathrm{N}_{2} \mathrm{O}$ emissions, respectively (Ciais et al., 2013; IPCC, 2019) while in Bangladesh it contributes $33 \%$ of agricultural GHG emissions (FAO, 2018). According to Wassmann et al. (2019), irrigated rice is the most potential source for emitting $70-80 \%$ of global $\mathrm{CH}_{4}$ followed by monsoon rice (15\%).

The International Rice Research Institute (IRRI) developed an alternating wetting and drying (AWD) irrigation strategy (Price et al., 2013) to save water and mitigate the emission of $\mathrm{CH}_{4}$ and $\mathrm{N}_{2} \mathrm{O}$ in rice fields instead of continual flooding (CF). Compared to $\mathrm{CF}$, AWD reduced $\mathrm{CH}_{4}$ and $\mathrm{N}_{2} \mathrm{O}$ emissions by 45-90\% (Linquist et al. 2014), and irrigation water usage by $15-35 \%$ without decreasing rice productivity (Siopongco et al., 2013). AWD was also found to lower arsenic deposition in grain by 64\% (Linquist et al., 2014). Leaching losses of soil N may also be decreased by reducing the percolation loss of irrigation water in AWD (Peng et al., 2011). AWD may increase the soil P status by increasing the number of aerobic microorganisms (Li et al., 2018) with a greater organic matter content by earthworm activities (Carrijo et al., 2017), hence, resulted in strong root anchoring, nutrient absorption, increased number of productive tillers, and eventually increased grain production (Yang et al., 2007). Apart from the saving of irrigation water by $70 \%$ and $\mathrm{CH}_{4}$ emissions by $97 \%$, AWD was rebuked for $33 \%$ yields loss while $\mathrm{N}_{2} \mathrm{O}$ emissions were more than quadrupled (Lagomarsino et al. 2016).

As discussed previously, the disparate effects of AWD on irrigation water use, GHGs emissions, and grain yields underscore the importance of additional research to increase our understanding of the relationships between cultivation practices, local environments, rice growth, and GHGs emissions. This information will be essential in assisting agricultural extension agencies and smallholder farmers for the implementation of AWD. The purpose of this on-farm study was to determine the prospective for AWD to reduce $\mathrm{CH}_{4}$ and $\mathrm{N}_{2} \mathrm{O}$ emissions and its effect 
on rice production and irrigation water saving in the farmers' rice fields at Feni and Chattogram districts of Bangladesh.

\section{Materials and methods}

\subsection{Experimental site and season}

On-farm participatory research trial was conducted at total 20 hectare land, 10 hectares under 62 farmers'

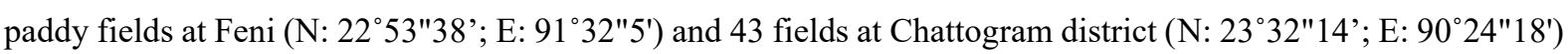
of Bangladesh during November 2017-April 2018. The locations have an average climate characteristic with annual mean rainfall of $498 \mathrm{~mm}$, maximum and minimum air temperature of 40 and $24^{\circ} \mathrm{C}$, respectively. The paddy soil is classified as clay-loam and loam, respectively. The soil properties are listed in Table 1.

Table 1

Chemical properties of soil $(0-15 \mathrm{~cm}$ depth) at study locations

\begin{tabular}{lcc}
\hline Properties & Feni & Chattogram \\
\hline $\mathrm{pH}$ & 7.2 & 7.42 \\
$\mathrm{OM}(\%)$ & 1.6 & 1.7 \\
Total N $(\%)$ & 0.13 & 0.14 \\
Available P $(\mathrm{ppm})$ & 10.8 & 11.5 \\
Available S $(\mathrm{ppm})$ & 77 & 82.8 \\
Exchangeable K $\left(\mathrm{Cmol} \mathrm{kg}^{-1}\right)$ & 0.16 & 0.18 \\
\hline
\end{tabular}

\subsection{Land preparation and transplanting}

A two-wheel tractor was used which included four rotary tillage passes and cross plowing, followed by two days of sun drying, and finally inundation and leveling. The fields were plowed and puddled thoroughly to about $10-\mathrm{cm}$ depth before transplanting. 35 days aged seedlings of BRRI dhan 28 were planted at $20 \times 20 \mathrm{~cm}$ spacing of rice hills to each plot.

\subsection{Installation of AWD pipes and water flow meter}

In each experimental field 15 farmers plots were selected randomly at different distance from water pump. PVC made AWD pipes were installed 10 days after transplanting @ 10 pipes in each bigha $\left(1335 \mathrm{~m}^{2}\right)$ of land. A farmer was treated as a replication in every location with two treatments such as of AWD and CF (Continuous Flooding). We installed a water flow meter at the front of outlet pipe of irrigation pump (Fig. 1) to measure the amount of water and time to irrigate the field AWD plots.

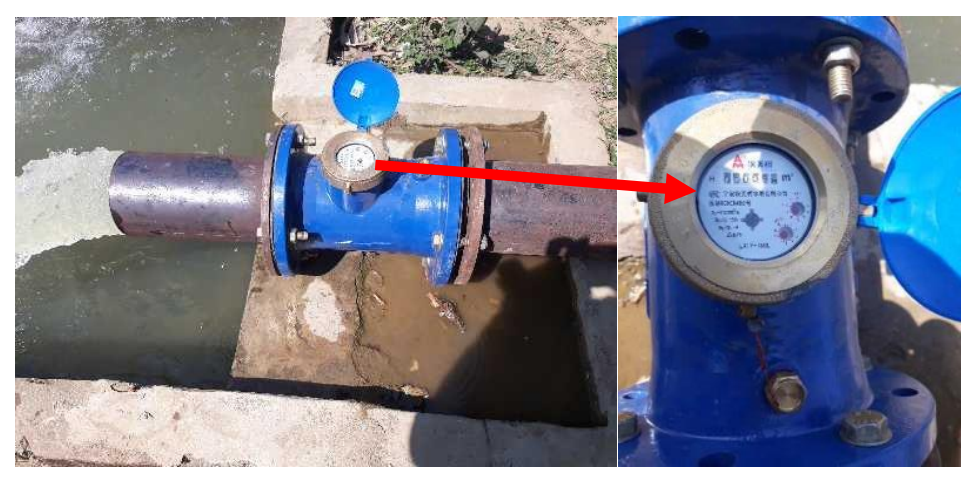

Fig. 1. Water flow meter 


\subsection{Irrigation management}

Field plots under AWD were irrigated following the principle of 'safe AWD' (Lampayan et al., 2015), where floodwater depth inside the AWD pipes was monitored every day and plots were re-flooded up to $5 \mathrm{~cm}$ when water depth dropped to $15 \mathrm{~cm}$ below the soil surface (Fig. 2). From one week before to one week after flowering (52-77 days), the field was kept flooded, topping up to a depth of $5 \mathrm{~cm}$. After flowering, during grain filling and ripening (79-100 days), the water level was dropped again to $15 \mathrm{~cm}$ below the soil surface before re-irrigation. AWD was suspended for 14 days after installation of pipes to assist suppression of the weeds by the ponded water and improve the efficacy of herbicides (pretilachlor). In CF irrigation method, fields were continuously flooded until two weeks before harvesting and field were irrigated regularly as and when needed.

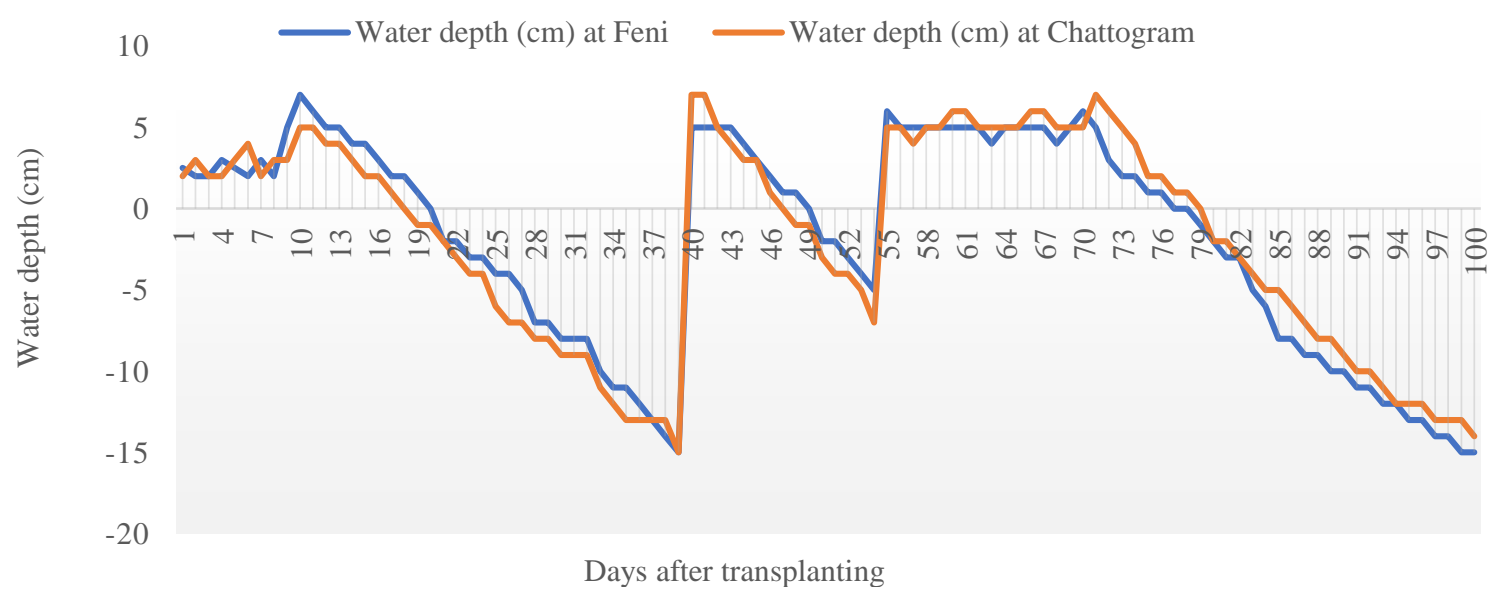

Fig. 2. Maintenance of water depth at different growth stages of rice

\subsection{Crop management}

Two to three rice seedlings hill ${ }^{-1}$ of 35 days old of BRRI dhan 28 were transplanted at $20 \times 20 \mathrm{~cm}^{\text {distance. }}$. Fertilizer management were adopted as per government recommendation. Phosphorus (triple super phosphate) and potassium (muriate of potash) were applied during final land preparation at 85 and $25 \mathrm{~kg} \mathrm{ha}^{-1}$, respectively. Sulfur (gypsum) and zinc (zinc sulphate) were applied to all plots as basal at the rate of 11 and $3 \mathrm{~kg} \mathrm{ha}^{-1}$, respectively. For nitrogen, prilled urea was applied as broadcast in three equal splits at 7-10 DAT, at maximum tillering and panicle initiation stages.

\subsection{Measurements}

Measurements such as crop growth duration (days), number of productive tillers $\mathrm{m}^{-2}$, number of grains panicle $^{-1}$, 1000-grains weight $(\mathrm{g})$, grain and straw yield $\left(\mathrm{t} \mathrm{ha}^{-1}\right)$ were collected. Crop was harvested a maturity from the central $2 \times 1.5 \mathrm{~m}$ area from three spots of each plot. The yield was calculated at $14 \%$ moisture content.

The emission of $\mathrm{CH}_{4}$ and $\mathrm{NO}_{2}$ were measured using the Cool Farm Tool Beta-3 (CFT) protocol (Haque et al., 2017).

GWP was calculated considering 28 for $\mathrm{CH}_{4}$ and 265 for $\mathrm{N}_{2} \mathrm{O}$ (IPCC, 2014) as follows-

GWP $\left(\mathrm{kg} \mathrm{CO}_{2}\right.$ equivalent ha $\left.{ }^{-1}\right)=\mathrm{CH}_{4} \times 28+\mathrm{CO}_{2} \times 1+\mathrm{N}_{2} \mathrm{O} \times 265$. (Where, amount of $\mathrm{CH}_{4}$ and $\mathrm{N}_{2} \mathrm{O}$ emission is $\mathrm{kg} \mathrm{ha}^{-1}$ and $\mathrm{CO}_{2} \mathrm{~kg} \mathrm{ha}^{-1}$ over a 100 -year time horizon) 
GHG emission intensity (GHGI) was calculated as follows:

GHGI = Total GWP/Grain yield (Haque et al., 2021).

The irrigation water savings was determined based on the numbers of required irrigation, and amount of water needed based on the readings of water flow meter. All these measurements were done for both AWD, and CF irrigation method.

\subsection{Data analysis}

Analysis of variance of the water productivity, paddy yield attributes and yield, seasonal cumulative emission of $\mathrm{CH}_{4}$ and $\mathrm{N}_{2} \mathrm{O}$ gases, GWP, and GHGI was performed with the Statistical Tool for Agricultural Research: STAR 2.0.1 (IRRI, 2014). All pair-wise mean comparison of treatments was done with The Duncans' Multiple Range Test at $\mathrm{p} \leq 0.05$ level of significance.

\section{Results}

\subsection{Water productivity and irrigation cost}

Irrigation method exerted a significant effect $(p \leq 0.05)$ on the water productivity both at Feni and Chattogram location of the study (Table 2). Data demonstrated that, the frequency of irrigation per hectare of land was approximately 20 times lower in AWD (65 and 56 at Feni and Chattogram, respectively) relative to CF (85 and 73 at two locations, respectively). One hectare of land under AWD method required total 3873 and $3382 \mathrm{~m}^{3}$ irrigation water at the Feni and Chattogram, respectively. These amounts were 24\% less than that of CF method at both the locations (5152 and $4454 \mathrm{~m}^{3} \mathrm{ha}^{-1}$, respectively). At Feni, the water productivity (WP) of AWD and CF method were 1.71 and $0.47 \mathrm{~kg} \mathrm{~m}^{-3}$, respectively; while at Chattogram the values were 1.50 and 0.52 , respectively. The mean values of WP for two locations revealed that, AWD required about $624 \mathrm{~L}$ irrigation water (excluding rainfall) to produce $1 \mathrm{~kg}$ paddy. On the contrary, $\mathrm{CF}$ required $2021 \mathrm{~L}$ irrigation water. On average of two locations, $224 \%$ higher WP was estimated in AWD over CF.

Table 2

Effect of irrigation methods on the water requirement and water productivity of paddy field at Feni and Chattogram districts

\begin{tabular}{ccccccc}
\hline \multirow{2}{*}{$\begin{array}{c}\text { Irrigation } \\
\text { method }\end{array}$} & \multicolumn{2}{c}{$\begin{array}{c}\text { Number of } \\
\text { irrigations ha }\end{array}$} & \multicolumn{2}{c}{$\begin{array}{c}\text { Amount of irrigation } \\
\left(\mathrm{m}^{3} \mathrm{ha}^{-1}\right)\end{array}$} & \multicolumn{2}{c}{$\begin{array}{c}\text { Water productivity } \\
\left(\mathrm{kg} \mathrm{m}^{-3}\right)\end{array}$} \\
\cline { 2 - 7 } & Feni & Chattogram & Feni & Chattogram & Feni & Chattogram \\
\hline CF & $85 \mathrm{a}$ & $73 \mathrm{a}$ & $5152.7 \mathrm{a}$ & $4454.5 \mathrm{a}$ & $0.47 \mathrm{~b}$ & $0.52 \mathrm{~b}$ \\
AWD & $65 \mathrm{~b}$ & $56 \mathrm{~b}$ & $3872.9 \mathrm{~b}$ & $3381.7 \mathrm{~b}$ & $1.71 \mathrm{a}$ & $1.50 \mathrm{a}$ \\
\hline CV (\%) & 31.35 & 25.71 & 31.64 & 28.80 & 10.95 & 9.81 \\
LSD $(0.05)$ & 3.93 & 3.77 & 234.21 & 202.27 & 0.16 & 0.17 \\
Stdv. & 23.52 & 16.60 & 1428.25 & 1128.66 & 0.57 & 0.61 \\
\hline
\end{tabular}

CF: Continuous flooding, AWD: Alternate wetting and drying, CV: Co-efficient of variance, LSD: Least significant variance, Stdv.: Standard deviation. Means with different letters indicate significant difference at the $5 \%$ level.

Locally the cost of single irrigation for one hectare paddy incurred US\$ 6.5 ( 1 US\$ $=85.46$ as on February 1, 2022), the mean of two study locations incurred US\$ 513.5 in CF and US\$ 393.25 in AWD. Hence, AWD saved $23.41 \%$ of associated irrigation cost. 


\subsection{Yield attributes and yield of paddy}

Rice yield was influenced significantly $(p \leq 0.05)$ by the irrigation methods at both the locations (Table 3$)$ of the present on-farm study which might have attributed to the significant variation of the number of productive tillers $\mathrm{m}^{-2}$ area. The AWD produced about 24\% higher number (1233 at Feni and 1311 at Chattogram) of productive tillers relative to CF (979 and 1045 at two locations, respectively). In the present study, on average of two locations, we found about 3\% higher paddy yield in AWD (5.96 and $6.24 \mathrm{t} \mathrm{ha}^{-1}$ ) over the CF (5.78 and $6.06 \mathrm{t}$ $\left.\mathrm{ha}^{-1}\right)$. The number of paddy grains panicle ${ }^{-1}$ and the weight of 1000-paddy grains did not vary significantly by the AWD and CF method. The paddy under AWD matured about one week earlier than CF across the locations.

Table 3

Effect of irrigation methods on the yield attributes and yield of paddy at Feni and Chattogram

\begin{tabular}{|c|c|c|c|c|c|c|c|c|c|c|}
\hline \multirow{2}{*}{$\begin{array}{l}\text { Irrigation } \\
\text { method }\end{array}$} & \multicolumn{2}{|c|}{$\begin{array}{c}\text { Growth } \\
\text { duration (days) }\end{array}$} & \multicolumn{2}{|c|}{$\begin{array}{l}\text { Productive tillers } \\
\mathrm{m}^{-2} \text { (no.) }\end{array}$} & \multicolumn{2}{|c|}{$\begin{array}{c}\text { Grains panicle }{ }^{-1} \\
\text { (no.) }\end{array}$} & \multicolumn{2}{|c|}{$\begin{array}{l}\text { 1000-grain } \\
\text { weight }(\mathrm{g})\end{array}$} & \multicolumn{2}{|c|}{$\begin{array}{l}\text { Grain yield } \\
\left(\mathrm{t} \mathrm{ha}^{-1}\right)\end{array}$} \\
\hline & Feni & Chattogram & Feni & Chattogram & Feni & Chattogram & Feni & Chattogram & Feni & Chattogram \\
\hline $\mathrm{CF}$ & $142 \mathrm{a}$ & $145 a$ & $979 b$ & $1045 b$ & 109 & 115 & 22.50 & 22.44 & $5.78 b$ & $6.06 \mathrm{~b}$ \\
\hline AWD & $135 \mathrm{~b}$ & $137 \mathrm{~b}$ & $1233 \mathrm{a}$ & $1311 \mathrm{a}$ & 114 & 113 & 22.55 & 22.53 & $5.96 \mathrm{a}$ & $6.24 \mathrm{a}$ \\
\hline $\mathrm{CV}(\%)$ & 0.84 & 0.95 & 0.46 & 1.01 & 5.69 & 7.31 & 5.57 & 4.04 & 6.91 & 3.79 \\
\hline $\operatorname{LSD}_{(0.05)}$ & 1.20 & 1.16 & 5.13 & 12.06 & 6.04 & 5.87 & 0.08 & 0.21 & 0.07 & 0.08 \\
\hline Stdv. & 5.30 & 4.99 & 129.60 & 137.01 & 19.52 & 18.33 & 0.32 & 0.24 & 0.44 & 0.25 \\
\hline
\end{tabular}

CF: Continuous flooding, AWD: Alternate wetting and drying, CV: Co-efficient of variance, LSD: Least significant variance, Stdv.: Standard deviation. Means with different letters indicate significant difference at the $5 \%$ level.

\section{3. $\mathrm{CH}_{4}$ emission}

There was a significant effect $(p \leq 0.01)$ of AWD and CF irrigation method on the emission of $\mathrm{CH}_{4}$ gas from the paddy field at both on-farm study locations (Fig. 3). A substantially higher amount of total emission was usually found in CF, followed by AWD. We estimated 93.2 and $83.7 \mathrm{~kg}$ less $\mathrm{CH}_{4} \mathrm{ha}^{-1}$ in AWD at Feni $(94.2 \mathrm{~kg}$ $\mathrm{ha}^{-1}$ ) and Chattogram (106.5 kg ha ${ }^{-1}$ ) which was about 49 and 44\% smaller than that of CF (187.4 and $190.1 \mathrm{~kg}$ $\mathrm{ha}^{-1}$ at two locations, respectively). Data indicated the $\mathrm{CH}_{4}$ emission factor for AWD was lower $\left(0.74 \mathrm{~kg} \mathrm{ha}^{-1} \mathrm{day}^{-}\right.$ $\left.{ }^{1}\right)$ compared to $\mathrm{CF}\left(1.39 \mathrm{~kg} \mathrm{ha}^{-1}\right.$ day $\left.^{-1}\right)$.

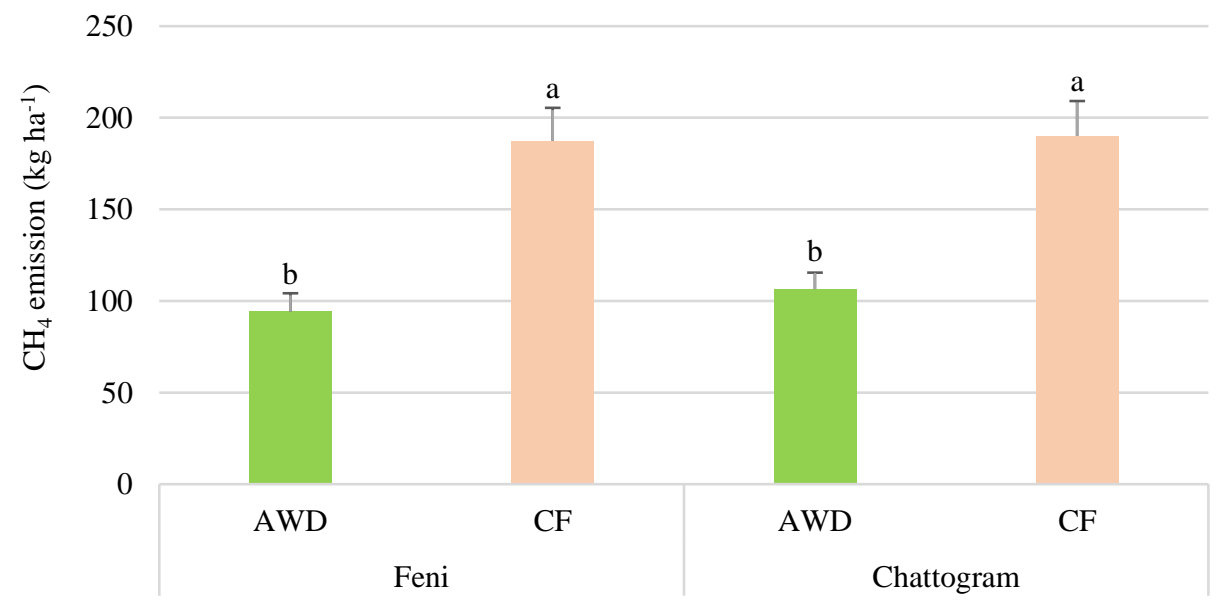

Fig. 3. Effect of AWD and CF irrigation methods on the $\mathrm{CH}_{4}$ emission from the paddy field at Feni and Chattogram. Means with different letters indicate significant difference at the $1 \%$ level. 


\section{4. $\mathrm{N}_{2} \mathrm{O}$ emission}

The emission of $\mathrm{N}_{2} \mathrm{O}$ was not varied significantly $(p \geq 0.05)$ by the irrigation methods at both Feni and Chattogram (Fig. 4). But numerically about 7\% higher amount of $\mathrm{N}_{2} \mathrm{O}$ was found in AWD both at Feni (10.7 kg $\left.\mathrm{ha}^{-1}\right)$ and Chattogram $\left(9.98 \mathrm{~kg} \mathrm{ha}^{-1}\right)$ than that of CF (9.96 and $9.31 \mathrm{~kg} \mathrm{ha}^{-1}$, respectively).

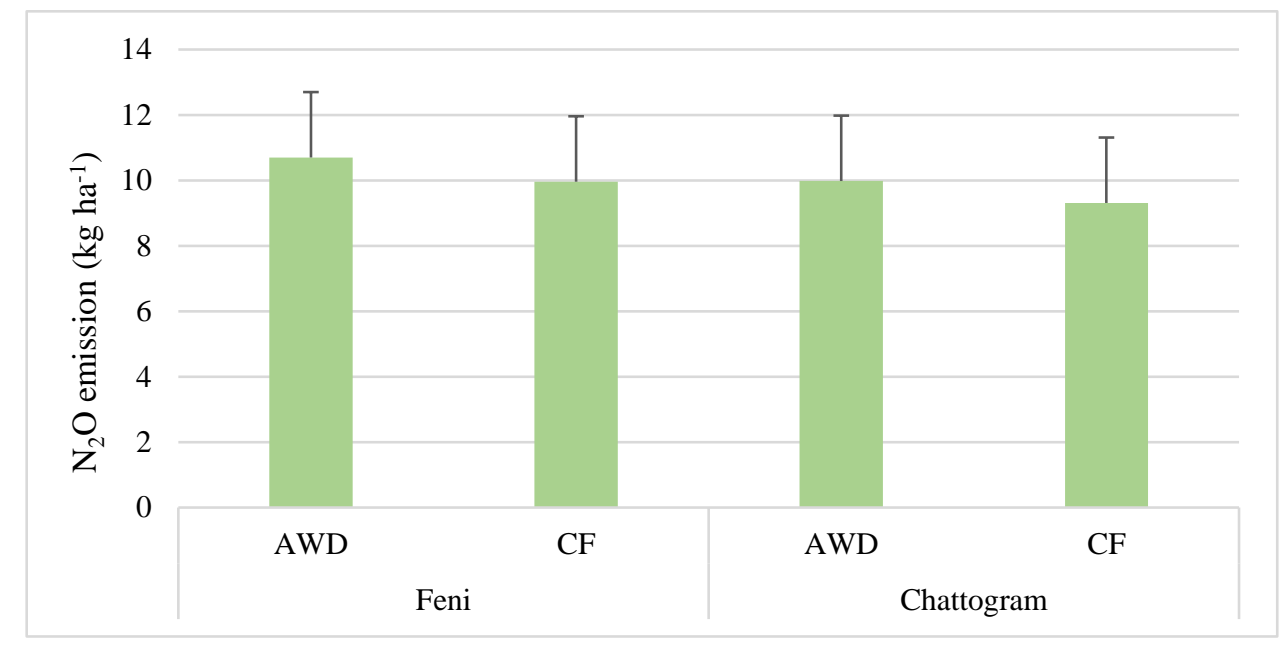

Fig. 4. Effect of AWD and CF irrigation methods on the $\mathrm{N}_{2} \mathrm{O}$ emission from the paddy field at Feni and Chattogram.

\subsection{The Global Warming Potential (GWP)}

The GWP was affected significantly $(p \leq 0.05)$ by the AWD and CF irrigation method at both the locations (Fig. 5). The higher share of GWP was found in CF than in AWD. The CF irrigation method produced $2231.6 \mathrm{~kg}$ higher $\mathrm{CO}_{2}$ eq. ha ${ }^{-1}$ GWP at Feni (5435 kg CO 2 eq. ha-1) and $2096.12 \mathrm{~kg}$ higher $\mathrm{CO}_{2}$ eq. ha ${ }^{-1} \mathrm{GWP}^{-1}$ at Chattogram (5516.1 kg CO 2 eq. ha ${ }^{-1}$ ) over AWD (3203.4 and $3419.98 \mathrm{~kg} \mathrm{CO}_{2}$ eq. ha ${ }^{-1}$, respectively) which were about 70 and $61 \%$ higher than that of AWD at Feni and Chattogram, respectively. Overall, the total GWP attributed to $\mathrm{CH} 4$ emissions was $95.04 \%$ in AWD and $97.19 \%$ in CF.

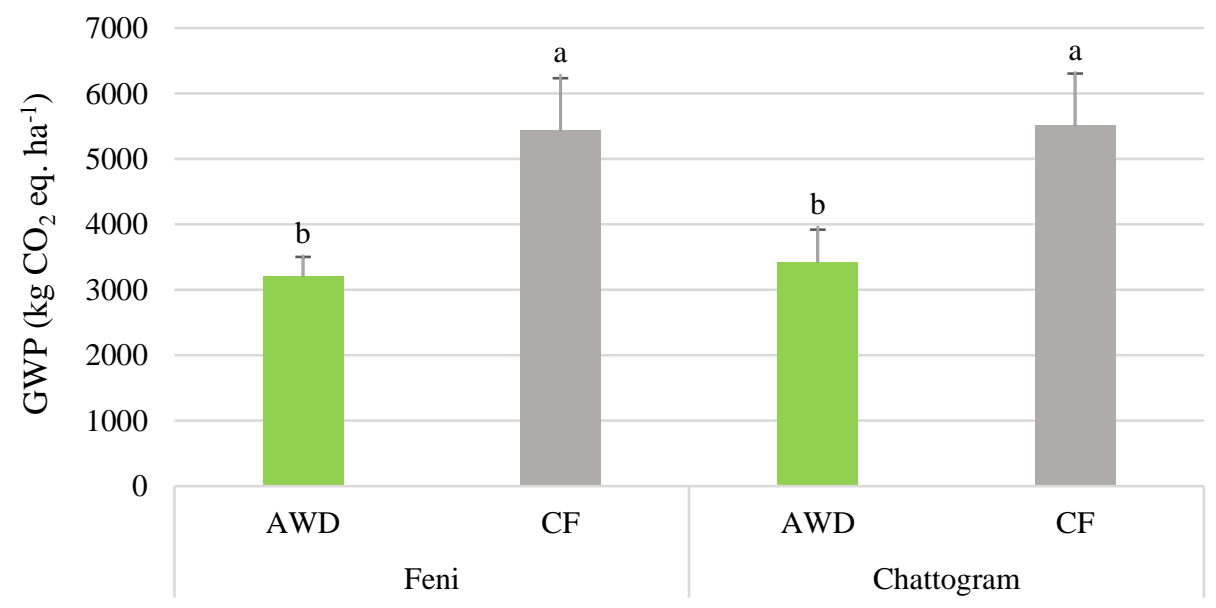

Fig. 5. Effect of AWD and CF irrigation methods on the GWP from the paddy field at Feni and Chattogram. Means with different letters indicate significant difference at the $5 \%$ level. 


\subsection{The intensity of $G H G$ emission (GHGI)}

The impact of irrigation method was significantly different $(p \leq 0.05)$ on the GHGI at both Feni and Chattogram (Figure 6). We found that, the GHGI of AWD was $43 \%$ and $40 \%$ smaller at Feni $\left(537.41 \mathrm{~kg} \mathrm{CO} \mathrm{CO}_{2}\right.$ eq. ton $\left.^{-1}\right)$ and Chattogram (546.32 $\mathrm{kg} \mathrm{CO}_{2}$ eq. ton $^{-1}$ ) than that of $\mathrm{CF}\left(940.31\right.$ and $910.23 \mathrm{~kg} \mathrm{CO}$ eq. ton $\left.{ }^{-1}\right)$. Data revealed that, production of each ton of paddy under AWD method attributed $537.41 \mathrm{~kg} \mathrm{CO}_{2}$ at Feni and 546.32 $\mathrm{kg} \mathrm{CO}_{2}$ at Chattogram, while $\mathrm{CF}$ was responsible to emit 940.31 and $910.23 \mathrm{~kg} \mathrm{CO}_{2}$, respectively.

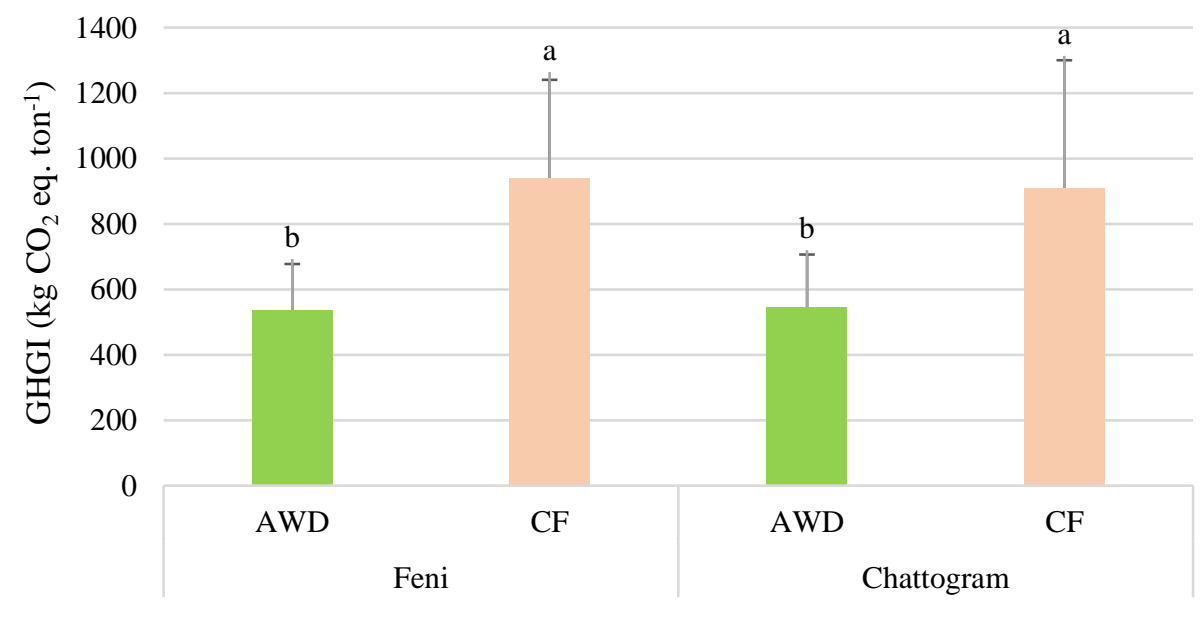

Fig. 6. Effect of AWD and CF irrigation methods on the GHGI of paddy production at Feni and Chattogram. Means with different letters indicate significant difference at the 5\% level.

\section{Discussion}

\subsection{Impact of irrigation method on water productivity}

AWD substantially $(p \leq 0.05)$ increased the quantity and amount of irrigation water used (Table 2). Consequently, AWD (mean across locations, $\left.1.60 \mathrm{~kg} \mathrm{~m}^{-3}\right)$ had a $224 \%$ greater water productivity than CF $(0.50$ $\mathrm{kg} \mathrm{m}^{-3}$ ). Water conservation is therefore a significant advantage of AWD at this study locations, since it needed 20 less number irrigation than CF. A similar conclusion was reached by (Rahman and Bulbul, 2014) who found that a season-long standing depth of water is not required for good rice yields and noted the highest $85.55 \mathrm{~kg} \mathrm{~cm}-$ ${ }^{3}$ water productivity in AWD. Again, a past study of Anbumozhi et al. (1998) shown an increase in water productivity of $1.26 \mathrm{~kg} \mathrm{~m}^{-3}$ in AWD plot when compared to CF $\left(0.96 \mathrm{~kg} \mathrm{~m}^{-3}\right)$. Feng et al. (2007) concluded that AWD for rice should be more widely used due to its potential to increase water productivity $3.27 \mathrm{~kg} \mathrm{~mm}^{-1}$ in AWD that is $19 \%$ higher than CF. They found irrigation water savings were 40-70\% without any yield loss by applying AWD. Water conservation in AWD systems may be ascribed in part to decreased percolation and seepage. Without flood water, percolation and seepage are substantially decreased; nevertheless, these losses are largely dependent on the hydrological characteristics of the soil (Carrijo et al., 2017). For example, Sharma et al. (2002) determined that $51 \%$ of total water input in a rice field is lost via percolation, whereas Linquist et al. (2015) found that about $15 \%$ of applied water is lost through percolation and seepage in clayey Californian rice soils. In this study, AWD used $25.7 \%$ less water on average than CF. AWD exposes fields to intermittent flooding (alternative cycles of saturated and unsaturated conditions), during which irrigation is stopped and water is 
allowed to recede until the soil reaches a specific moisture level, at which point the field is flooded. When compared to CF systems, AWD has been shown to minimize water inputs by 23\% (Bouman and Tuong, 2001). AWD substantially decreased irrigation water consumption by 34\% (Carrijo et al., 2017) and 23.4\% (Chidthaisong et al., 2018) when compared to CF. Around 23.4-42.6\% of water was found to be saved in AWD without compromising paddy yields (Yang et al., 2017). Additionally, a group of researchers observed irrigation water savings of 35\% (Zhang et al., 2009) and 30\% (Devkota et al., 2013) when AWD is used instead of CF.

Saving about $24 \%$ of irrigation water resulted in a $23.41 \%$ reduction in irrigation expenses in our research. This result is consistent with earlier findings that AWD may help decrease irrigation expenses by lowering pumping costs and fuel usage (Lampayan et al., 2015). Reduced irrigation was linked with a decrease in irrigation costs between 12 and 15\%, indicating a significant benefit of AWD irrigation for resource-scarce farmers (Shahe Alam et al., 2009). Additionally, Neogi et al. (2018) projected a cost reduction of 35\% with AWD irrigation over $\mathrm{CF}$ irrigation. Although the number of irrigations and related irrigation costs were significantly decreased in AWD, the benefits accrued directly to the pump owners due to the fixed-rate agreement reached at the outset of the season between the pump owner and farmers. Under the AWD approach, farmers pay a fixed price per unit area regardless of the number of irrigations administered during the paddy growing season. To really benefit from AWD technology in Bangladesh, a Famers' Community-Based, Pre-paid Card Metering and Buried Pipe Irrigation System should be implemented.

\subsection{Impact of irrigation method on paddy yield}

We observed a 3\% increase in rice production in AWD compared to CF (Table 3), which may be attributable to a $24 \%$ in productive tillers. Although the number of panicles and the weight of 1000 grains were both constant numerically in AWD and CF. Increased paddy yields under AWD are primarily due to decreased redundant vegetative growth and improved canopy structure and root growth (Chu et al., 2015; Zhou et al., 2017); elevated hormonal levels, most notably increases in abscisic acid levels during soil drying and cytokinin levels during rewatering; and enhanced carbon remobilization from vegetative tissues to grain (Zhang et al., 2010; Zhang et al., 2012). Yang et al. (2009) observed an increase in rice yields under AWD due to a rise in the percentage of productive tillers, a decrease in the angle of the uppermost leaves, which allows more sunlight to penetrate the canopy, and a shift in shoot and root activity. In Nepal, a group of researchers found no significant difference in rice yields between AWD and CF, with AWD saving 57\% of irrigation water (Howell et al., 2015). Rice fields with a 120-200 times greater soil oxygen content and more carbon release from the rice roots under AWD than under CF result in increased microbial populations and biomass in the rice rhizosphere, as well as increased rice production (Tian et al., 2013; Subedi and Poudel, 2021). The strong root development under AWD vs. CF more effectively absorbs water and nutrients, resulting in a greater rice grain production (Wang et al., 2016). Drying the rhizosphere modifies plant hormone signaling and increases grain filling rate (Zhang et al., 2010). The considerably greater number of productive tillers in AWD than in CF contributes to AWD's higher yield (Howell et al., 2015).

It is still disputed if the AWD irrigation system has the potential to reduce or sustain grain yields. AWD may result in higher nitrogen losses through nitrification and denitrification, resulting in decreased plant nitrogen absorption (Pandey et al., 2014). Increased numbers of tillers and effective tillers under AWD may have resulted in increased competition for plant resources between tillers and panicles, resulting in substantially reduced grain 
weight, quantity, and filling (Peng and Bouman, 2007). In comparison, a reduced tiller count under AWD was offset by increased grain weight and a higher percentage of grain filling per panicle, resulting in improved yield (Bouman and Tuong, 2001). A meta-analysis of 56 research including 528 side-by-side comparisons between AWD, and CF showed that AWD reduced rice grain production by 5.4 percent owing to water stress (Carrijo et al., 2017). However, Rahman and Bulbul (2014) asserts that a little amount of water stress on the plant does not result in a reduction in grain production. He found that water levels 15 to $25 \mathrm{~cm}$ below ground level in AWD had no effect on the total number of filled grains, while $5 \mathrm{~cm}$ standing water in $\mathrm{CF}$ did, and that such standing water throughout the season is not necessary for good rice yields. Additionally, certain research from southeast China indicates that using an AWD irrigation technique may result in an improvement in grain production (Chu et al., 2015; Zhou et al., 2017). The factors outlined above may have resulted in an increase in paddy yield in AWD over $\mathrm{CF}$ in this research. The variations across research are due to differences in soil hydrological conditions and irrigation techniques used at different times (Yang et al., 2017). This demonstrates the need for further research on the impact of AWD on rice production in Bangladesh.

\subsection{Impact of irrigation method on the emission of GHGs and the intensity of GHG}

Irrigation method under AWD and $\mathrm{CF}$ influenced the amount of $\mathrm{CH}_{4}$ emitted by rice production. In this research, AWD irrigation substantially $(\mathrm{p} \leq 0.05)$ decreased $\mathrm{CH}_{4}$ emissions on average about $47 \%(49 \%$ at Feni and $44 \%$ at Chattogram) when compared to CF irrigation (Fig. 3). These findings corroborate earlier findings (Ku et al., 2017; Li et al., 2018; Islam et al., 2020). When AWD irrigation is managed correctly, significant reductions in $\mathrm{CH}_{4}$ emissions are anticipated. AWD's efficacy in lowering $\mathrm{CH}_{4}$ emissions is dependent on the efficiency of water management, the kind of soil, and other cultivation techniques (Xu et al., 2015). Intermittent aeration oxygenates the soil, resulting in the oxidation of $\mathrm{CH}_{4}$ by methanotrophs, resulting in a decrease in $\mathrm{CH}_{4}$ emission. According to some estimates, up to $80 \%$ of the $\mathrm{CH}_{4}$ generated during the rice growing season is oxidized by methanotrophs (Singh et al., 2010). In comparison, CF rice cultivation anaerobicifies the soil environment, lowering the redox potential, which promotes the anaerobic breakdown of complex organic substrates by methanogens, which ultimately results in $\mathrm{CH}_{4}$ generation over AWD (Minamikawa et al., 2006).

The technique of irrigation had no significant effect $(\mathrm{p} \geq 0.05)$ on the fluctuation of $\mathrm{N}_{2} \mathrm{O}$ in this research (Fig. 4). Although $\mathrm{N}_{2} \mathrm{O}$ emissions from rice fields grown under AWD were about $7 \%$ higher than those from paddy fields cultivated under CF conditions in Feni and Chattogram. Changing water regimes from CF to AWD influences the intensity of nitrification and denitrification, depending on the availability of oxygen. The topsoil layer becomes aerobic throughout a drying cycle, while the bottom soil layer stays anaerobic even when the water level reaches $15 \mathrm{~cm}$ below the soil surface. Thus, large amounts of $\mathrm{N}_{2} \mathrm{O}$ are generated because of microbial nitrification of $\mathrm{NH}_{4}{ }^{+}$and denitrification of $\mathrm{NO}_{3}{ }^{-}$(Islam et al, 2020). While $\mathrm{N}_{2} \mathrm{O}$ generation declines at very high moisture levels, it rises in fields with repeated wet and dry spells (Brentrup et al., 2000). By contrast, some prior research indicates that $\mathrm{CF}$ enhances $\mathrm{N}_{2} \mathrm{O}$ emission, and the higher the soil moisture, the larger the $\mathrm{N}_{2} \mathrm{O}$ emission (Baggs et al., 2000; Yano et al., 2014). By contrast, the reduced $\mathrm{N}_{2} \mathrm{O}$ emission peaks under CF conditions are most likely the result of additional denitrification to $\mathrm{N}$ under severe anaerobic conditions (Zou et al., 2005).

AWD irrigation reduced GWP by $43 \%$ as compared to $\mathrm{CF}$ irrigation. These results demonstrate that $\mathrm{CH}_{4}$ emissions are completely responsible for the global warming potential of rice fields. Although $\mathrm{N}_{2} \mathrm{O}$ has a much higher radiative force than $\mathrm{CH}_{4}$, its emissions are very insignificant. Thus, $\mathrm{CH}_{4}$ is the main source of greenhouse 
gas emissions in rice cultivation, accounting for more than 90\% of total GWP emissions (Sander et al., 2014; Janz et al., 2019). In this study, the total GWP related with $\mathrm{CH}_{4}$ emissions was $95 \%$ AWD and $97 \%$ in $\mathrm{CF}$, while $\mathrm{N}_{2} \mathrm{O}$ contributed only by $1 \%$ to GWP. These results are consistent with previous studies (Sander et al., 2017; Islam et al., 2018; Oo et al., 2018). As was previously observed for GWP, AWD irrigation showed the potential to reduce GHGI by $41 \%$ when compared to CF irrigation (Islam et al., 2018; Li et al., 2018). Therefore, the most successful strategies for lowering GWP and GHGI in rice production should focus on reducing $\mathrm{CH}_{4}$ emissions.

\section{Conclusion}

We studied the efficacy of AWD in terms of water savings, paddy production, and GHG emissions in farmers' paddy fields at Feni and Chattogram districts in Bangladesh. The irrigation water consumption was significantly decreased by $24 \%$ in AWD with $224 \%$ greater water productivity. Hence, the irrigation costs were saved by $23.41 \%$ than the CF. By this time the paddy yield was improved significantly by $3 \%$ in AWD compared to CF. The AWD decreased seasonal $\mathrm{CH}_{4}$ emissions by $47 \%$ than $\mathrm{CF}$ but no effect on seasonal $\mathrm{N}_{2} \mathrm{O}$ emissions. In AWD, the intensity of GHG was $42 \%$ lower relative to CF. Simultaneous accomplishment of increased grain production, water conservation, and acceptable GHG emission reduction is a prerequisite for AWD adoption by existing local farmers since water and environmental conservation are not reflected in the farmers' profit in the country. Field experiments demonstrating AWD's capability should be conducted in Bangladesh under a variety of agroecological zones, soil types, and farmer management circumstances. To make AWD profitable to farmers, rather than pump owners, a community-based, prepaid card-metering subsurface irrigation system should be established.

\section{Declaration of competing interest}

The authors state that they have no known conflicting financial or personal interests that may seem to have influenced the work described in this article.

\section{Acknowledgements}

The authors would like to extend their heartfelt gratitude to Asian Develop Bank (ADB) to fund International Rice Research Institute (IRRI) under the project Climate-smart practices and varieties for intensive rice-based systems in Bangladesh and Cambodia (IRRI Ref. No. A-2016-167).

\section{References}

Anbumozhi, V., Yamaji, E., Tabuchi, T., 1988. Rice crop growth and yield as influenced by changes in ponding water depth, water regime and fertigation level. Agric. Water Manag. 37 (3), 241-253. https://doi.org/10.1016/S0378-3774(98)00041-9

Baggs, E.M., Rees, R.M., Smith, K.A., Vinten, A.J.A., 2000. Nitrous oxide emission from soils after incorporating crop residues. Soil Use Manag. 16, 82-87. https://doi.org/10.1111/j.1475-2743.2000.tb00179.x

BBS, 2020. Bangladesh Bureau of Statistics, Statistical Yearbook Bangladesh 2020, 40 ${ }^{\text {th }}$ Edition. Statistics and Informatics Division, Ministry of Planning, Government of the People's Republic of Bangladesh, 569p. Available at: www.bbs.gov.bd. Accessed date: 18 June 2021.

Bouman, B.A.M., 2009. How much water does rice use? Rice Today. 8 (1), 28-29. https://ricetoday.irri.org/howmuch-water-does-rice-use/

Bouman, B.A.M., Hengsdijk, H., Hardy, B., Bindraban, P.S., Tuong, T.P., Ladha, J.K., 2002. Water-wise rice production. International Rice Research Institute. http://books.irri.org/9712201821_content.pdf 
Bouman, B.A.M., Tuong, T.P. 2001. Field water management to save water and increase its productivity in irrigated lowland rice. Agric. Water Manag. 49, 11-30. https://doi.org/10.1016/S0378-3774(00)00128-1

Brentrup, F., Küsters, J., Lammel, J., Kuhlmann, H., 2000. Methods to estimate on-field nitrogen emissions from crop production as an input to LCA studies in the agricultural sector. Int. J. Life Cycle Assess. 5, 349357. https://doi.org/10.1007/BF02978670

Carrijo, D.R., Lundy, M.E., Linquist, B.A., 2017. Rice yields and water use under alternate wetting and drying irrigation: A meta-analysis. Field Crops Res. 203, 173-180 http://dx.doi.org/10.1016/j.fcr.2016.12.002

Chidthaisong, A., Chaun, N., Rossopa, B., Buddaboon, C., Kunuthai, C., Sriphirom, P., Towprayoon, S., Tokida, T., Padre, A.T., Minamikawa, K., 2018. Evaluating the effects of alternate wetting and drying (AWD) on methane and nitrous oxide emissions from a paddy field in Thailand. Soil Sci. Plant Nutr. 64:1, 31 38. https://doi.org/10.1080/00380768.2017.1399044

Chu, G., Wang, Z.Q., Zhang, H., Liu, L.J., Yang, J.C., Zhang, J.H., 2015. Alternate wetting and moderate drying increases rice yield and reduces methane emission in paddy field with wheat straw residue incorporation. Food Energy Secur. 4, 238-254. https://doi.org/10.1002/fes3.66.

Ciais, P., Sabine, C., Bala, G., 2013. Carbon and other biogeochemical cycles.In Climate Change 2013: The Physical Science Basis. Contribution of Working Group I to the Fifth Assessment Report of the Intergovernmental Panel on Climate Change, Eds. Stocker TF, Qin D, Plattner G-K et al. Cambridge University Press, Cambridge, UK and New York, NY.

Devkota, K.P., Manschadi, A.M., Lamers, J.P.A., Humphreys, E., Devkota, M., Egamberdiev, O., Gupta, R.K., Sayre, K.D., Vlek, P.L.G., 2013. Growth and yield of rice (Oryza sativa L.) under resource conservation technologies in the irrigated drylands of Central Asia. Field Crops Res. 149, 115-126. https://doi.org/10.1016/j.fcr.2013.04.015

FAO, 2018. FAOSTAT Data (available at: http://www.fao.org/faostat/en/\#data [Accessed on 12 December 2021).

Feng, L., Bouman, B.A.M., Tuong, T.P., Cabangon, R.J., Li, Y., Lu, G., Feng, Y., 2007. Exploring options to grow rice using less water in northern China using a modelling approach: I. Field experiments and model evaluation. Agric. Water Manag. 88 (1-3), 1-13. https://doi.org/10.1016/j.agwat.2006.10.006

Haque, M.M., Biswas, J.C., 2021. Emission factors and global warming potential as influenced by fertilizer management for the cultivation of rice under varied growing seasons. Environ. Res. 197, 111156. https://doi.org/10.1016/j.envres.2021.111156

Haque, M.M., Biswas, J.C., Maniruzzaman, M., Choudhury, A.K., Naher, U.A, Hossain M.B., Akhter S., Ahmed, F., Kalra N., 2017. Greenhouse gas emissions from selected cropping patterns and adaptation strategies in Bangladesh. Int. J. Dev. Res. 7 (11), 16832-16838. http://www.journalijdr.com/sites/default/files/issue-pdf/10909.pdf

Howell, K.R., Shrestha, P., Dodd, I.C., 2015. Alternate wetting and drying irrigation-maintained rice yields despite half the irrigation volume but is currently unlikely to be adopted by smallholder lowland rice farmers in Nepal. Food Energy Secur. 4 (2), 144-157. https://doi.org/10.1002/fes3.58

IPCC, 2014. Climate change 2014: synthesis report. In: Pachauri, R.K., meyer, L.A. (Eds.), Core Writing Team, Contribution of Working Group I, II and III to the Fifth Assessment Report of the Intergovernmental Panel on Climate Change. IPCC, Geneva, Switzerland, p. 151. https://www.ipcc.ch/site/assets/uploads/2018/05/SYR_AR5_FINAL_full_wcover.pdf

IPCC, 2019. Refinement to the 2006 IPCC guidelines for national greenhouse gas inventories, 4. AFOLU (Chapter 5) Cropland 49TH SESSION OF THE IPCC, 8 - 12 May 2019, Kyoto, Japan. https://www.ipcc.ch/2019/

IRRI, 2014. International Rice Research Institute, Statistical Tool for Agricultural Research (STAR), Biometrics and Breeding Informatics, PBGB Division, International Rice Research Institute, Los Baños, Laguna, The Philippines. http://bbi.irri.org/products

Islam, S.F., van Groenjgen, J.W., Jensen, L.S., Sander, B.O., de Neergaard, A., 2018. The effective mitigation of greenhouse gas emissions from rice paddies without compromising yield by early-season drainage. Sci. Total Environ. 612, 1329-1339. https://doi.org/10.1016/j.scitotenv.2017.09.022.

Islam, S.M.M., Gaihre Y.K., Islam, M.R., Akter, M., Mahmud, A.A., Singh, U., Sander. B.O., 2020. Effects of water management on greenhouse gas emissions from farmers' rice fields in Bangladesh. Sci. Total Environ. 734, 139382. https://doi.org/10.1016/j.scitotenv.2020.139382 
Janz, B., Weller, S., Kraus, D., Racela, H.R., Wassmann, R., Butterbach-Bahl, K., Kiese, R., 2019. Greenhouse gas footprint of diversifying rice cropping systems: impacts of water regime and organic amendments. Agric. Ecosyst. Environ. 270-271, 41-54. https://doi.org/10.1016/j.agee.2018.10.011.

Ku, H.H., Hayashi, K., Agbisit, R., Villegas-Pangga, G., 2017. Evaluation of fertilizer and water management effect on rice performance and greenhouse gas intensity in different seasonal weather of tropical climate. Sci. Total Environ. 601-602, 1254-1262. https://doi.org/10.1016/j.scitotenv.2017.05.277

Kürschner, E., Henschel, C., Hildebrandt, T., Jülich, E., Leineweber, M., Paul, C., 2010.Water saving in rice production-dissemination, adoption and short term impacts of alternate wetting and drying (AWD) in Bangladesh. SLE Publication Series S 241. Zerbe Druck \& Werbung, Berlin, Germany. https://edoc.huberlin.de/bitstream/handle/18452/3838/241.pdf?sequence $=1$

Lagomarsino, A., Agnelli, A.E., Linquist, B., Adviento-Borbe, M.A., Agnelli, A., Gavina, G., Ravaglia, S., Ferrara, M., 2016. Alternate wetting and drying of rice reduce $\mathrm{CH}_{4}$ emissions but triggered $\mathrm{N}_{2} \mathrm{O}$ peaks in a clayey soil of Central Italy. Pedospere, 46, 533-548. https://doi.org/10.1016/S1002-0160(15)600637

Lampayan, R.M., Rejesus, R.M., Singleton, G.R., Bouman, B.A., 2015. Adoption and economics of alternate wetting and drying water management for irrigated lowland rice. Field Crops Res, 170, 95-108. https://doi.org/10.1016/j.fcr.2014.10.013

Li, J., Wan, Y., Wang, B., Waqas, M.A., Cai, W., Guo, C., Zhou, S., Su, R., Qin, X., Gao, Q., Wilkes, A., 2018. Combination of modified nitrogen fertilizers and water saving irrigation can reduce greenhouse gas emissions and increase rice yield. Geoderma. 315, 1-10. https://doi.org/10.1016/j.geoderma.2017.11.033

Li, Z., Li, Z., Letuma, P., Zhao, H., Zhang, Z., Lin, W., Lin, W., 2018. A positive response of rice rhizosphere to alternate moderate wetting and drying irrigation at grain filling stage. Agric. Water Manag. 207, 26-36. https://doi.org/10.1016/j. agwat.2018.05.022

Linquist, B.A., Anders, M.M., Adviento-Borbe, M.A.A., Chaney, R.L., Nalley, L.L., da Rosa, E.F.F., van Kessel, C., 2014. Reducing greenhouse gas emissions, water use, and grain arsenic levels in rice systems. Glob. Change Biol. 21, 407-417. https://doi.org/10.1111/gcb.12701

Linquist, B.A., Snyder, R., Anderson, F., 2015. Water balances and evapotranspiration in water- and dry-seeded rice systems. Irrig. Sci. 33, 375-385. https://doi.org/10.1007/s00271-015-0474-4

Minamikawa, K., Sakai, N., Yagi, K., 2006. Methane emission from paddy fields and itsmitigation options on a field scale. Microbes and Environ. 21, 135-147. http://dx.doi.org/10.1264/jsme2.21.135

Neogi, M.G., Uddin, A.K.M.S., Uddin, M.T., Miah, M.A.H., 2018. Alternate wetting and drying (AWD) technology: A way to reduce irrigation cost and ensure higher yields of Boro rice. J. Bangladesh Agric. Univ. 16 (1), 1-4. https://doi.org/10.3329/jbau.v16i1.36471

Oo, A.Z., Sudo, S., Inubushi, K., Mano, M., Yamamoto, A., Ono, K., Osawa, T., Hayashida, S., Patra, P.K., Terao, Y., Elayakumar, P., Vanitha, K., Umamageswari, C., Jothimani, P., Ravi, V., 2018. Methane and nitrous oxide emissions from conventional and modified rice cultivation systems in South India. Agric. Ecos. Environ. 252, 148-158. https://doi.org/10.1016/j.agee.2017.10.014

Pandey, A., Mai, V.T., Vu, D.Q., Bui, T.P.L., Mai, T.L.A., Jensen, L.S., Neergaard, A., 2014. Organic matter and water management strategies to reduce methane and nitrous oxide emissions from rice paddies in Vietnam. Agric. Ecos. Environ. 196, 137-146. https://doi.org/10.1016/j.agee.2014.06.010

Peng, S. and Bouman, B.A.M., 2007. Prospects for genetic improvement to increase lowland rice yields with less water and nitrogen. In: Spiertz, J.H.J., Struik, P.C. and Laar, H.H. Van (eds). 2007, Scale and complexity in plant systems research: Gene-plant-crop relations. Dordrecht, The Netherlands: Springer. pp. 251-266. https://www.springer.com/gp/book/9781402059049

Peng, S.Z., Yang, S.H., Xu, J.Z., Luo, Y.F., Hou, H.J., 2011. Nitrogen and phosphorus leaching losses from paddy fields with different water and nitrogen managements. Paddy Water Environ. 9 (3), 333-342. http://dx.doi.org/10.1007/s10333-010-0246-y

Price, A.H., Norton, G.J., Salt, D.E., Ebenhoeh, O., Meharg, A.A., Meharg, C., 2013. Alternate wetting and drying irrigation for rice in Bangladesh: is it sustainable and has plant breeding something to offer? Food Energy Secur. 2, 120-129. https://doi.org/10.1002/fes3.29 
Rahman, M.R., Bulbul, S.H., 2014. Effect of alternate wetting and drying (AWD) irrigation for boro rice cultivation in Bangladesh. Agriculture, Forestry and Fisheries. 3 (2), 86-92. https://doi.org/10.11648/j.aff.20140302.16

Sander, B.O., Samson, M., Buresh, R.J., 2014. Methane and nitrous oxide emissions from flooded rice fields as affected by water and straw management between rice crops. Geoderma. 235-236, 355-362. https://doi.org/10.1016/j.geoderma.2014.07.020.

Sander, B.O., Wassmann, R., Palao, L.K., Nelson, A., 2017. Climate-based suitability assessment for alternate wetting and drying water management in the Philippines: a novel approach for mapping methane mitigation potential in rice production. Carbon Manag. 3004, 1-12. https://doi.org/10.1080/17583004.2017.1362945.

Shahe Alam, M., Islam, M.S., Salam, M.A., Islam M.A., 2009. Economics of Alternate Wetting and Drying Method of Irrigation: The Agriculturists. 7 (1\&2): 82-89. http://dx.doi.org/10.3329/agric.v7i1.5258

Sharma, P.K., Lav, Bhushan, Ladha, J.K., Naresh, R.K., Gupta, R.K., Balasubramanian, B.V., Bouman, B.A.M., 2002. Crop-water relations in rice-wheat cropping under different tillage systems and water-management practices in a marginally sodic, medium-textured soil. In: Bouman, B.A.M., Hengsdijk, H., Hardy, B., Bindraban, P.S., Tuong, T.P., Ladha, J.K. (Eds.), Water-wise Rice Production. International Rice Research Institute, Los Banos, Philippines, pp. 223-235. http://books.irri.org/9712201821_content.pdf

Singh, J.S., Pandey, V.C., Singh, D.P., Singh, R.P., 2010. Influences of pyrite and farmyard manure on population dynamics of soil methanotroph and rice yield in saline rainfed field. Agric. Ecosyst. Environ. 139, 7479. https://doi.org/10.1016/j.agee.2010.07.003.

Siopongco, J.D.L.C., Wassmann, R., Sander, B.O., 2013. Alternate wetting and drying in Philippine rice production: Feasibility study for a Clean Development Mechanism. Tech. Bull. 2013, 17, 14. Available online: http://books.irri.org/TechnicalBulletin17_content.pdf (accessed on 21 August2021).

Subedia, N., Poudel, S., 2021. Alternate wetting and drying technique and its impacts on rice production. Tropical Agrobiodiversity. 2 (1), 1-6. http://doi.org/10.26480/trab.01.2021.01.06

Tian, J., Pausch, J., Fan, M., Li, X., Tang, Q., Kuzyakov, Y., 2013. Allocation and dynamics of assimilated carbon in rice-soil system depending on water management. Plant Soil. 363, 273-285 (2013). https://doi.org/10.1007/s11104-012-1327-z

USDA (United States Department of Agriculture), 2019. Economic Research Service, USDA, 2019. https://www.ers.usda.gov/topics/farm-practices-management/irrigation-water-use/

Wang, Z.P., Zhang, W., Beebout, S., Zhang, H., Liu, L., Yang, J., Zhang, J., 2016. Grain yield, water and nitrogen use efficiencies of rice as influenced by irrigation regimes and their interaction with nitrogen rates. Field Crops Res. 193, 54-69. https://doi.org/10.1016/j. fcr.2016.03.006

Wassmann, R., Villanueva, J., Khounthavong, M., Okumu, B., Vo, T., Sander, B., 2019. Adaptation, mitigation and food security: multi-criteria ranking system for climate-smart agriculture technologies illustrated for rainfed rice in Laos. Glob. Food Secur. 23, 33-40. https://doi.org/10.1016/j.gfs.2019.02.003

Xu, Y., Ge, J., Tian, S., Li, S., Nguy-Robertson, A.L., Zhan, M., Cao, C., 2015. Effects of water saving irrigation practices and drought resistant rice variety on greenhouse gas emissions from a no-till paddy in the central lowlands of China. Sci. Total Environ. 505, 1043-1052. https://doi.org/10.1016/j.scitotenv.2014.10.073

Yang, J.C., Huang, D.F., Duan, H., Tan, G.L., Zhang, J.H., 2009. Alternate wetting and moderate soil drying increases grain yield and reduces cadmium accumulation in rice grains. J. Sci. Food Agric. 89, 17281736. https://doi.org/10.1002/jsfa.3648.

Yang, J.C., Liu, K., Wang, Z. Q., Du, Y., Zhang, J.H., 2007. Water-saving and high-yielding irrigation for lowland rice by controlling limiting values of soil water potential. J. Integr. Plant Biol. 49, 1445-1454. https://doi.org/10.1111/j.1672-9072.2007.00555.x.

Yang, J.C., Zhou, Q., Zhang, J., 2017. Moderate wetting and drying increases rice yield and reduces water use, grain arsenic level, and methane emission. The Crop Journal. 5, 151-158. https://doi.org/10.1016/j.cj.2016.06.002.

Yano, M., Toyoda, S., Tokida, T., Hayashi, K., Hasegawa, T., Makabe, A., Koba, K., Yoshida, N., 2014. Isotopomer analysis of production, consumption and soil-to-atmosphere emission processes of $\mathrm{N}_{2} \mathrm{O}$ at 
the beginning of paddy field irrigation. Soil Biol. Biochem., 70, 66-78. https://doi: 10.1016/j.soilbio.2013.11.026

Zhang, H., Chen, T.T., Wang, Z.Q., Yang, J.C., Zhang, J.H., 2010. Involvement of cytokinins in the grain filling of rice under alternate wetting and drying irrigation. J. Exp. Bot. 61, 3719-3733. https://doi.org/10.1093/jxb/erq198.

Zhang, H., Li, H.W., Yuan, L.M., Wang, Z.Q., Yang, J.C., Zhang, J.H., 2012. Post-anthesis alternate wetting and moderate soil drying enhances activities of key enzymes in sucrose-to-starch conversion in inferior spikelets of rice. J. Exp. Bot. 63, 215-227. https://doi.org/10.1093/jxb/err263.

Zhang, H., Xue, Y.G., Wang, Z.Q., Yang, J.C., Zhang, J.H., 2009. An alternate wetting and moderate soil drying regime improves root and shoot growth in rice. Crop Sci. 49, 2246-2260. https://doi.org/10.2135/cropsci2009.02.0099.

Zhou, Q., Ju, C.X., Wang, Z.Q., Zhang, H., Liu, L.J., Yang, J.C., Zhang, J.H., 2017. Grain yield and water use efficiency of super rice under soil water deficit and alternate wetting and drying irrigation. J. Integr. Agric. 16, 1028-1043. https://doi.org/10.1016/S2095-3119(16)61506-X.

Zou, J., Huang, Y., Jiang, J., Zheng, X., Sass, R.L., 2005. A 3-year field measurement of methane and nitrous oxide emissions from rice paddies in China: effects of water regime, crop residue, and fertilizer application. Global Biogeochem. Cy. 19, 1-9. https://doi.org/10.1029/2004GB002401 